\title{
Folate-Modified Photoelectric Responsive Polymer Microarray as Bionic Artificial Retina to Restore Visual Function
}

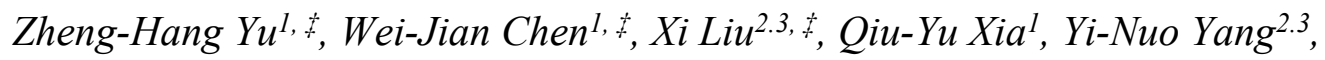
Mei Dong' , Jia-Hao Liü, Huai-Jin Guan ${ }^{2.3 *}$, Cheng Sun ${ }^{2 *}$, Fu-De Feng ${ }^{1 *}$, QunDong Shen ${ }^{1 *}$

1 Department of Polymer Science \& Engineering and Key Laboratory of High Performance Polymer Materials \& Technology of MOE, School of Chemistry \& Chemical Engineering, Nanjing University, Nanjing 210023, China. E-mail: qdshen@nju.edu.cn; fengfd@nju.edu.cn

2 Key Laboratory for Neuroregeneration of Jiangsu Province and Ministry of Education, Co-innovation Center of Neuroregeneration, Nantong University, Nantong 226001, China. Email: suncheng1975@ntu.edu.cn

3 Eye Institute, Affiliated Hospital of Nantong University, Nantong 226001, China. Email: guanhjeye@163.com 
Methods

All of chemicals were purchased from commercial sources and used as received unless otherwise stated. NMR spectra were measured on a Bruker DPX-400 spectrometer. GPC analysis was run on a Shimadzu LC20 AD liquid chromatography system equipped with a RID-20A differential refractive index detector against monodisperse polystyrene standards. THF was used as the eluent at a flow rate of $1.0 \mathrm{~mL} \mathrm{~min}{ }^{-1}$.

Synthesis of Monomer. Details of synthesis and characterization of monomer was provided in the Figures S1.

The compound 5-(3-thienyl)pentanoic acid (compound 1) was synthesized according to previous report ${ }^{1}$.

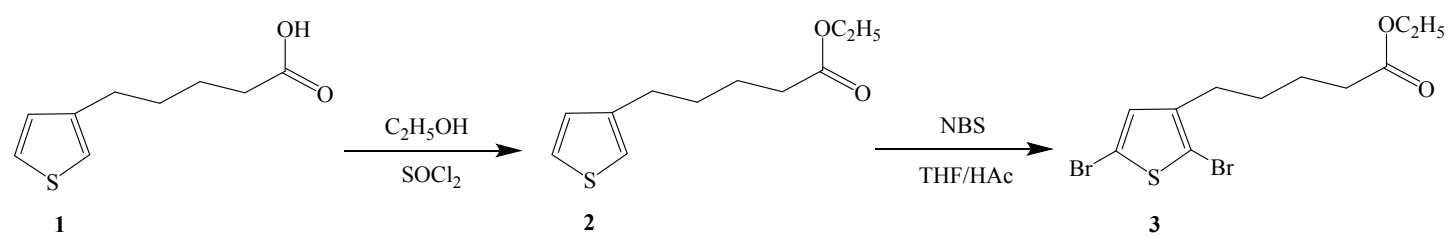

Compound $1(3.68 \mathrm{~g}, 20 \mathrm{mmol})$ was added to $50 \mathrm{~mL}$ of ethanol containing a few drops of $\mathrm{SOCl}_{2}$ in a $250 \mathrm{~mL}$ flask. The mixture was stirred for $24 \mathrm{~h}$ at room temperature. After evaporation of solvent under vacuum, the residue was purified by flash chromatography on silica gel using hexane/ethyl acetate (80/20) as eluent to afford ethyl 5-(thiophen-3yl)pentanoate (compound 2, 3.82 g, 18 mmol). Yield: 90\%. 1H NMR (400 MHz, $\left.\mathrm{CDCl}_{3}\right): \delta(\operatorname{ppm} 7.32-7.12(\mathrm{~m}, 1 \mathrm{H}), 6.92(\mathrm{~d}, \mathrm{~J}=4.3 \mathrm{~Hz}, 2 \mathrm{H}), 4.12(\mathrm{q}, \mathrm{J}=7.1 \mathrm{~Hz}, 2 \mathrm{H})$, $2.65(\mathrm{~d}, \mathrm{~J}=6.9 \mathrm{~Hz}, 2 \mathrm{H}), 2.32(\mathrm{t}, \mathrm{J}=6.5 \mathrm{~Hz}, 2 \mathrm{H}), 1.76-1.55(\mathrm{~m}, 4 \mathrm{H}), 1.24(\mathrm{t}, \mathrm{J}=7.0$ $\mathrm{Hz}, 3 \mathrm{H}) ; 13 \mathrm{C}$ NMR (100 MHz, CDCl3): $\delta$ (ppm) 173.62, 142.45, 128.17, 125.27, $120.07,60.45,60.25,34.35,34.15,30.00,29.93,24.61,24.43,14.30$. 

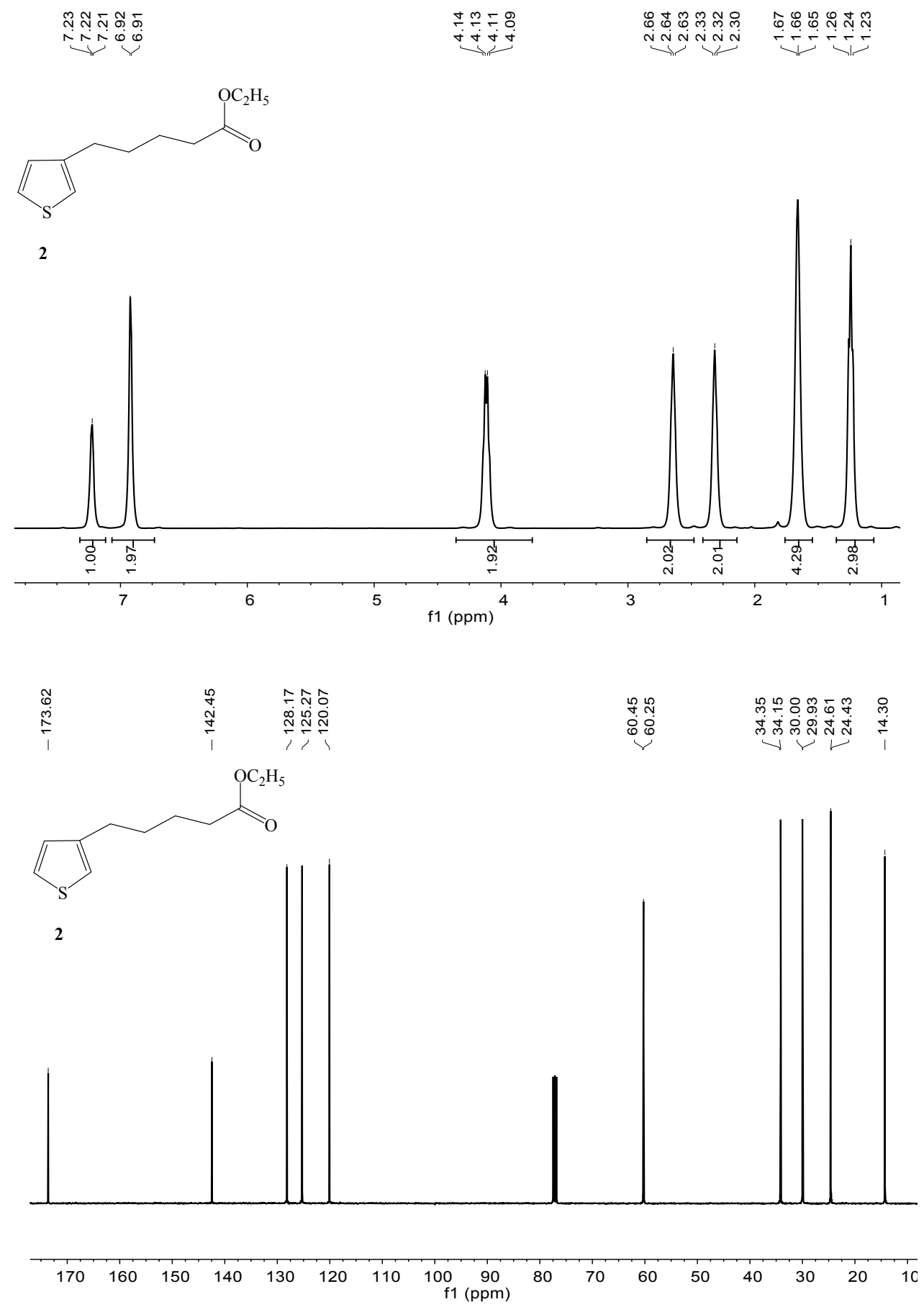

Figure S1. ${ }^{1} \mathrm{H}$ NMR and ${ }^{13} \mathrm{C}$ NMR spectra of compound 2 in $\mathrm{CDCl}_{3}$.

To a solution of compound $2(2.12 \mathrm{~g}, 10 \mathrm{mmol}) \mathrm{in} \mathrm{THF} / \mathrm{CH}_{3} \mathrm{COOH}(5 \mathrm{~mL} / 5 \mathrm{~mL})$ was added 2.4 equivalent molar NBS, and the mixture was stirred at room temperature for 2 h. After chloroform $(10 \mathrm{~mL})$ was added, the mixture was successively washed with 
distilled water and aqueous sodium bicarbonate. The organic layer was dried and concentrated under vacuum. The residue was purified by flash chromatography on silica gel using hexane/ethyl acetate $(80 / 20)$ as the eluent to afford ethyl 5-(2,5dibromothiophen-3-yl)pentanoate (compound 3, $3.25 \mathrm{~g}, 8.8 \mathrm{mmol}$ ). Yield: $88 \%$. $1 \mathrm{H}$ NMR (400 MHz, $\left.\mathrm{CDCl}_{3}\right): \delta(\mathrm{ppm}) 6.78(\mathrm{~s}, 1 \mathrm{H}), 4.13(\mathrm{q}, \mathrm{J}=7.2 \mathrm{~Hz}, 2 \mathrm{H}), 2.31-2.55$ $(\mathrm{dt}, \mathrm{J}=83.6,7.3 \mathrm{~Hz}, 4 \mathrm{H}), 1.63(\mathrm{dp}, \mathrm{J}=23.6,7.6 \mathrm{~Hz}, 4 \mathrm{H}), 1.26(\mathrm{t}, \mathrm{J}=7.1 \mathrm{~Hz}, 3 \mathrm{H}) ; 13 \mathrm{C}$ NMR (100 MHz, CDCl3): $\delta(\mathrm{ppm}) 173.45,142.25,130.84,110.54,108.63,108.24$ $77.38,77.26,77.06,76.74,66.71,66.39,60.34,50.00,34.02,33.93,33.52,29.58,29.13$ $29.01,28.22,24.36,14.29$. 

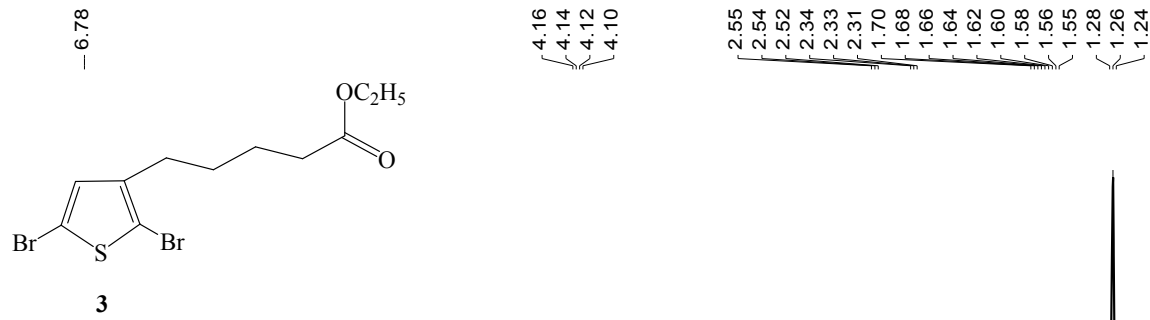

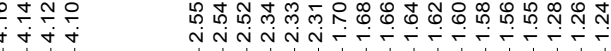
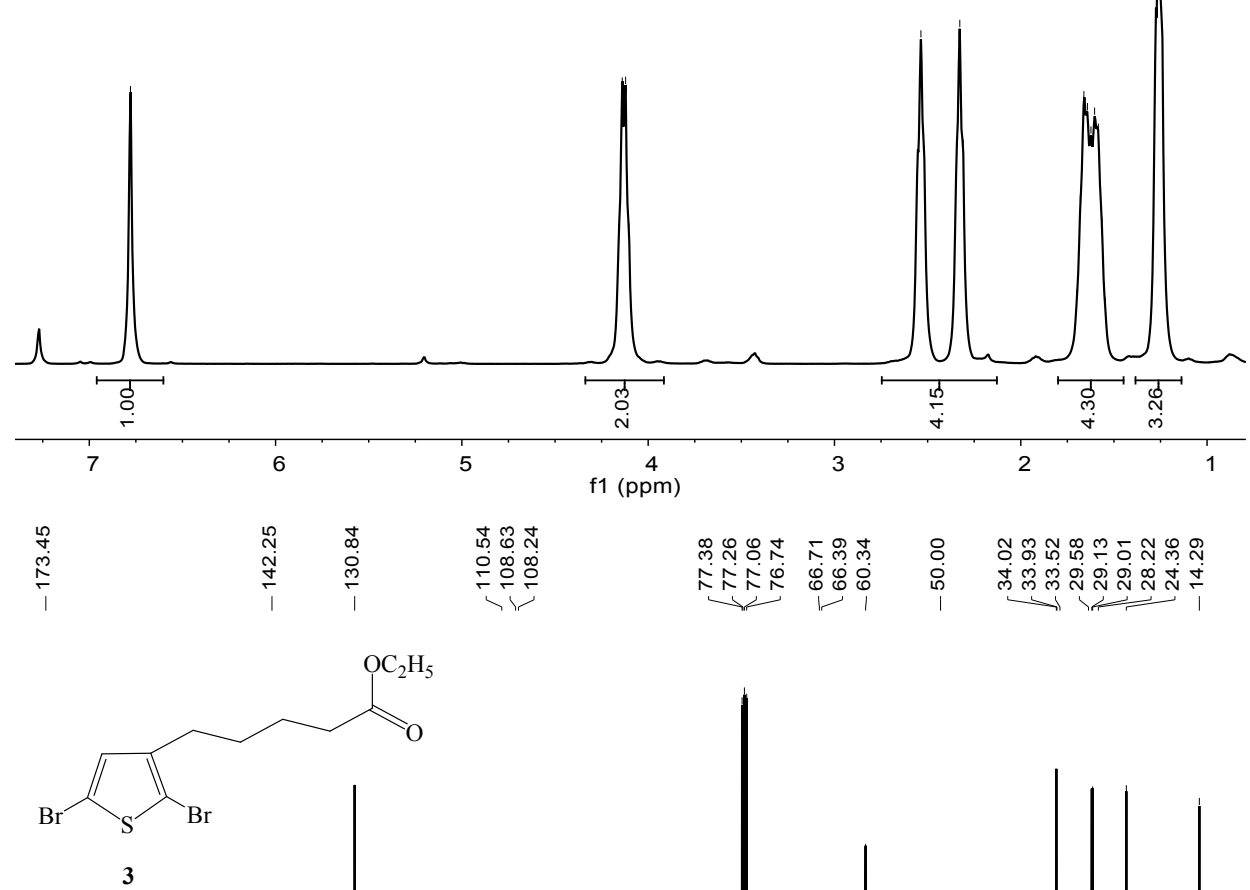

疋占占

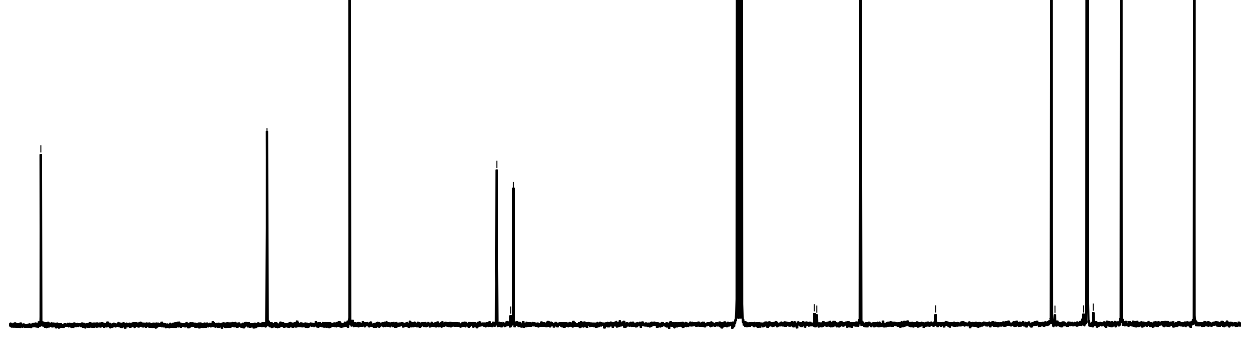

$\begin{array}{lllllllllllllllll}170 & 160 & 150 & 140 & 130 & 120 & 110 & 100 & 90 & 80 & 70 & 60 & 50 & 40 & 30 & 20 & 10\end{array}$

Figure S2. ${ }^{1} \mathrm{H}$ NMR and ${ }^{13} \mathrm{C}$ NMR spectra of compound 3 in $\mathrm{CDCl}_{3}$.

General Procedure for the Polymerization of Monomer (compound 3):

Monomer (5 mmol) was dissolved in THF $(25 \mathrm{~mL})$ and cooled to $-40{ }^{\circ} \mathrm{C}$ under an argon atmosphere. To this solution was added i-PrMgCl $\cdot \mathrm{LiCl}(1.3 \mathrm{M}$ in THF, 4.94 
mmol) via a syringe over a period of $5 \mathrm{~min}$. The mixture was stirred under argon for 1 $\mathrm{h}$ at $-40{ }^{\circ} \mathrm{C}$. After quick warming up to $0{ }^{\circ} \mathrm{C}, 20 \mathrm{~mL}$ of the solution via a syringe was added into a new flask containing $54.2 \mathrm{mg}$ of $\mathrm{Ni}(\mathrm{dppp}) \mathrm{Cl}_{2}(0.1 \mathrm{mmol})$. The mixture was stirred at $0{ }^{\circ} \mathrm{C}$ for $1 \mathrm{~h}$ and then quenched by addition of $0.5 \mathrm{~mL}$ of $1.0 \mathrm{M}$ aq. $\mathrm{HCl}$. After filtration, solvent was removed under reduced pressure. The residue was redissolved in chloroform, successively washed by aq. $\mathrm{NH}_{4} \mathrm{Cl}$, brine, and water, and dried over anhydrous $\mathrm{MgSO}_{4}$ to yield an orange solution. After evaporation, multiple methanol precipitation, filtration, and vacuum drying treatments, the polymer products were obtained. GPC (THF): $\mathrm{Mn}=11.8 \mathrm{kDa}, \mathrm{d}=1.11 .1 \mathrm{H} \mathrm{NMR}\left(400 \mathrm{MHz}, \mathrm{CDCl}_{3}\right): \delta$ (ppm) $6.78(\mathrm{~s}, \mathrm{CH}), 4.13\left(\mathrm{q}, \mathrm{CH}_{2}\right), 2.31-2.55\left(\mathrm{dt}, \mathrm{CH}_{2}\right), 1.63\left(\mathrm{dp}, \mathrm{CH}_{2}\right), 1.26\left(\mathrm{t}, \mathrm{CH}_{3}\right)$.
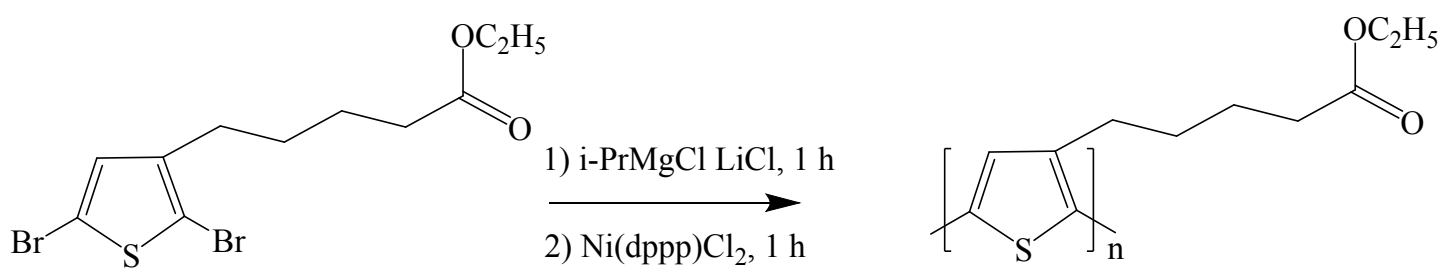

Figure S3. Synthesis of P3EPT 


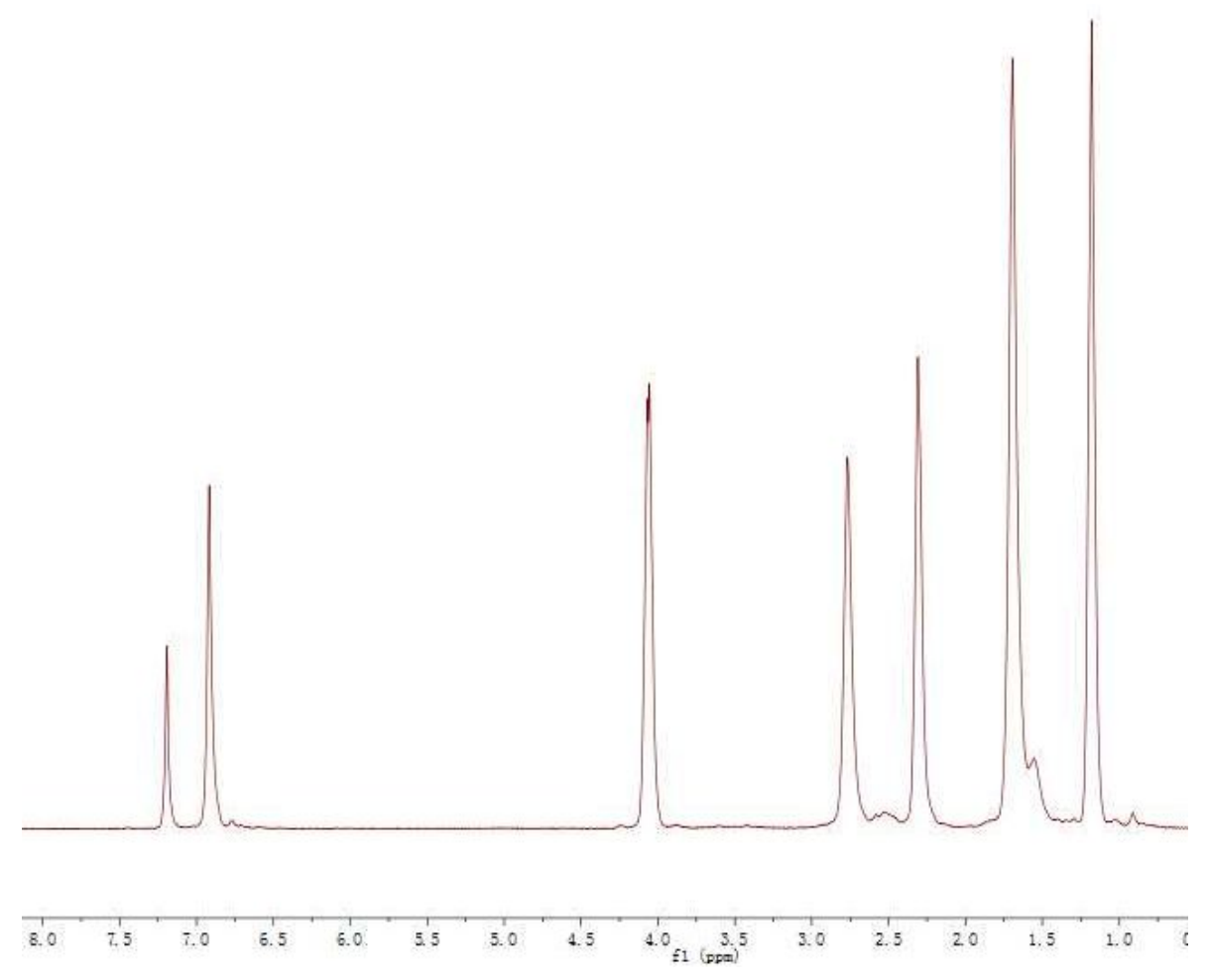

Figure S4. ${ }^{1} \mathrm{H}$ NMR spectrum of P3EPT in $\mathrm{CDCl}_{3}$.

\section{Synthesis of P3EPT-FA:}
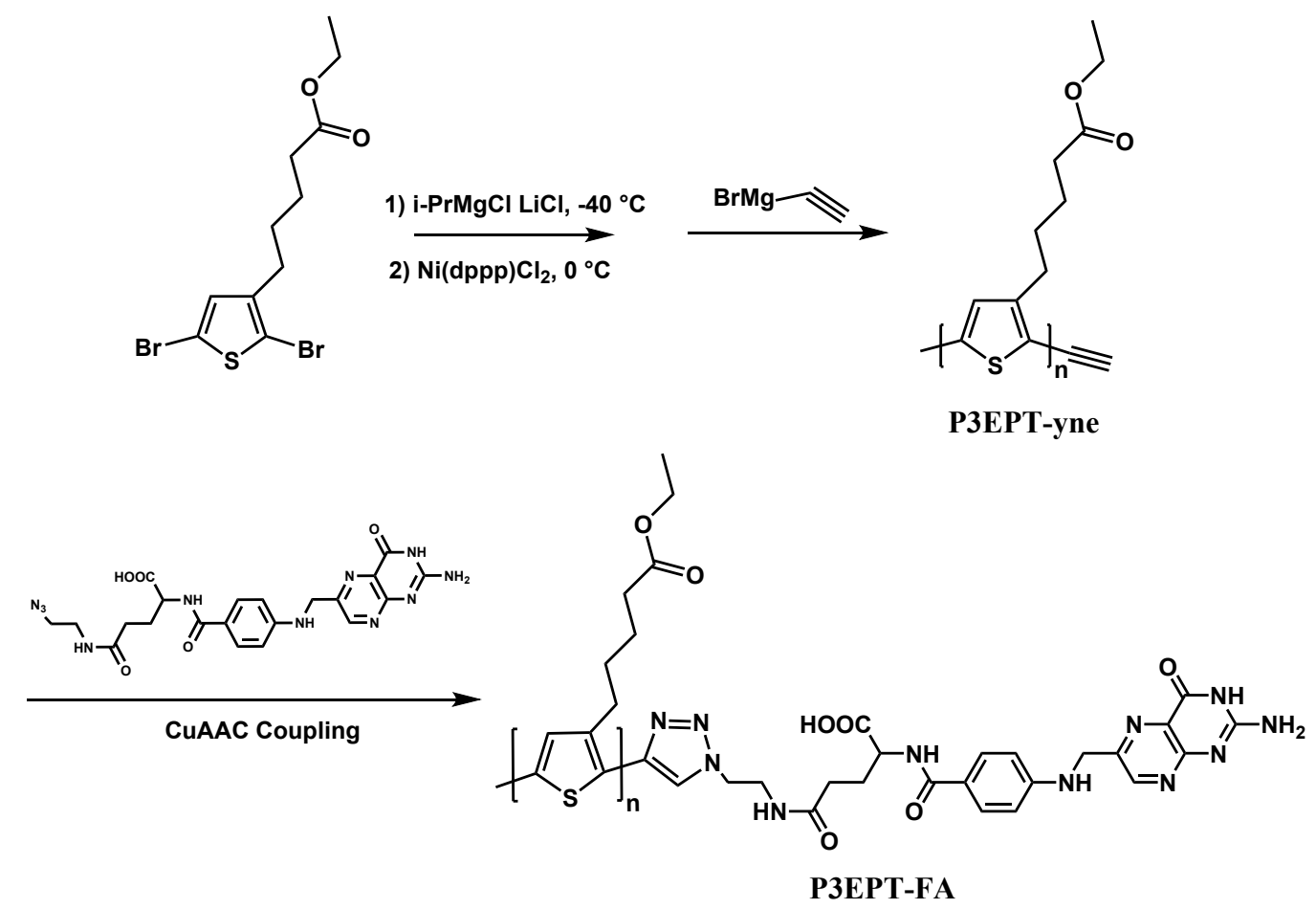

Figure S5. Synthesis of P3EPT-FA. 
Monomer $(2 \mathrm{mmol})$ was dissolved in THF $(20 \mathrm{~mL})$ and cooled to $-40{ }^{\circ} \mathrm{C}$ under an argon atmosphere. To this solution was added $\mathrm{i}-\mathrm{PrMgCl} \cdot \mathrm{LiCl}(1.3 \mathrm{M}$ in $\mathrm{THF}, 1.96$ mmol) via a syringe over a period of $5 \mathrm{~min}$. The mixture was stirred under argon for 1 $\mathrm{h}$ at $-40{ }^{\circ} \mathrm{C}$. After quick warming up to $0{ }^{\circ} \mathrm{C}, 20 \mathrm{~mL}$ of the solution via a syringe was added into a new flask containing $54.2 \mathrm{mg}$ of $\mathrm{Ni}(\mathrm{dppp}) \mathrm{Cl}_{2}(0.1 \mathrm{mmol})$. The mixture was stirred at $0{ }^{\circ} \mathrm{C}$ for $1 \mathrm{~h}$, followed by adding ethynylmagnesium chloride $(2 \mathrm{mmol}$, $0.5 \mathrm{M}$ in THF) via syringe. The mixture was stirred at $0{ }^{\circ} \mathrm{C}$ for additional $10 \mathrm{~min}$ and then quenched by addition of $0.5 \mathrm{~mL}$ of $1.0 \mathrm{M}$ aq. $\mathrm{HCl}$. After filtration, solvent was removed under reduced pressure. The residue was redissolved in chloroform, successively washed by aq. $\mathrm{NH}_{4} \mathrm{Cl}$, brine, and water, and dried over anhydrous $\mathrm{MgSO}_{4}$ to yield an orange solution. After evaporation, multiple methanol precipitation, filtration, and vacuum drying treatments, the polymer products P3EPT-yne were obtained.

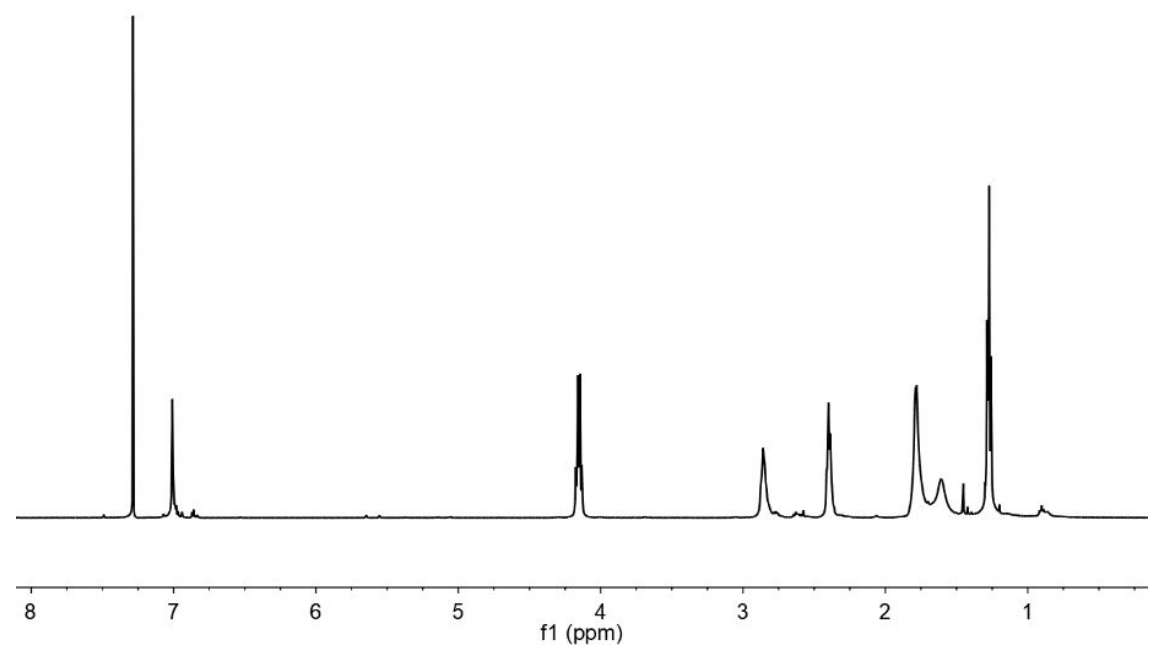


Figure S6. ${ }^{1} \mathrm{H}$ NMR spectrum of P3EPT-yne in $\mathrm{CDCl}_{3}$.

P3EPT-yne (100 mg, $26.8 \mu \mathrm{mol})$ and folate azide $^{2}(31.0 \mathrm{mg}, 60.0 \mu \mathrm{mol})$ were dissolved in a mixture of THF $(15 \mathrm{~mL})$ and DMSO $(15 \mathrm{~mL})$. Sodium ascorbate $(3 \mathrm{mg}, 5 \mu \mathrm{mol})$ and copper sulfate pentahydrate $(1.5 \mathrm{mg}, 6 \mu \mathrm{mol})$ were added. The reaction mixture was stirred for $48 \mathrm{~h}$ at room temperature, and precipitated in methanol. After filtration, the precipitation was washed with DMSO $(3 \times 50 \mathrm{~mL})$, distilled water $(3 \times 50 \mathrm{~mL})$, and then dried under vacuum to yield P3EPT-FA.

$\underset{+}{+}$

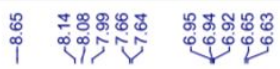<smiles>NCCNC(=O)CCC(NC(=O)c1ccc(NCc2cnc3nc(N)[nH]c(=O)c3n2)cc1)C(=O)O</smiles>
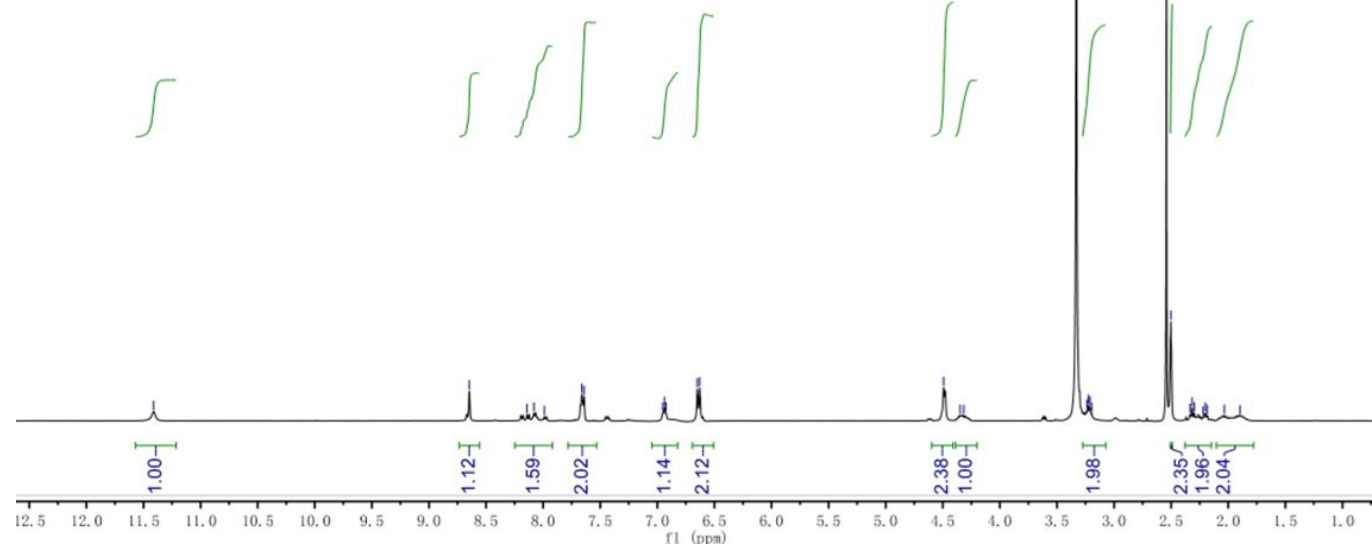

Figure S7. ${ }^{1} \mathrm{H}$ NMR spectrum of folate-azide in DMSO-d6. 


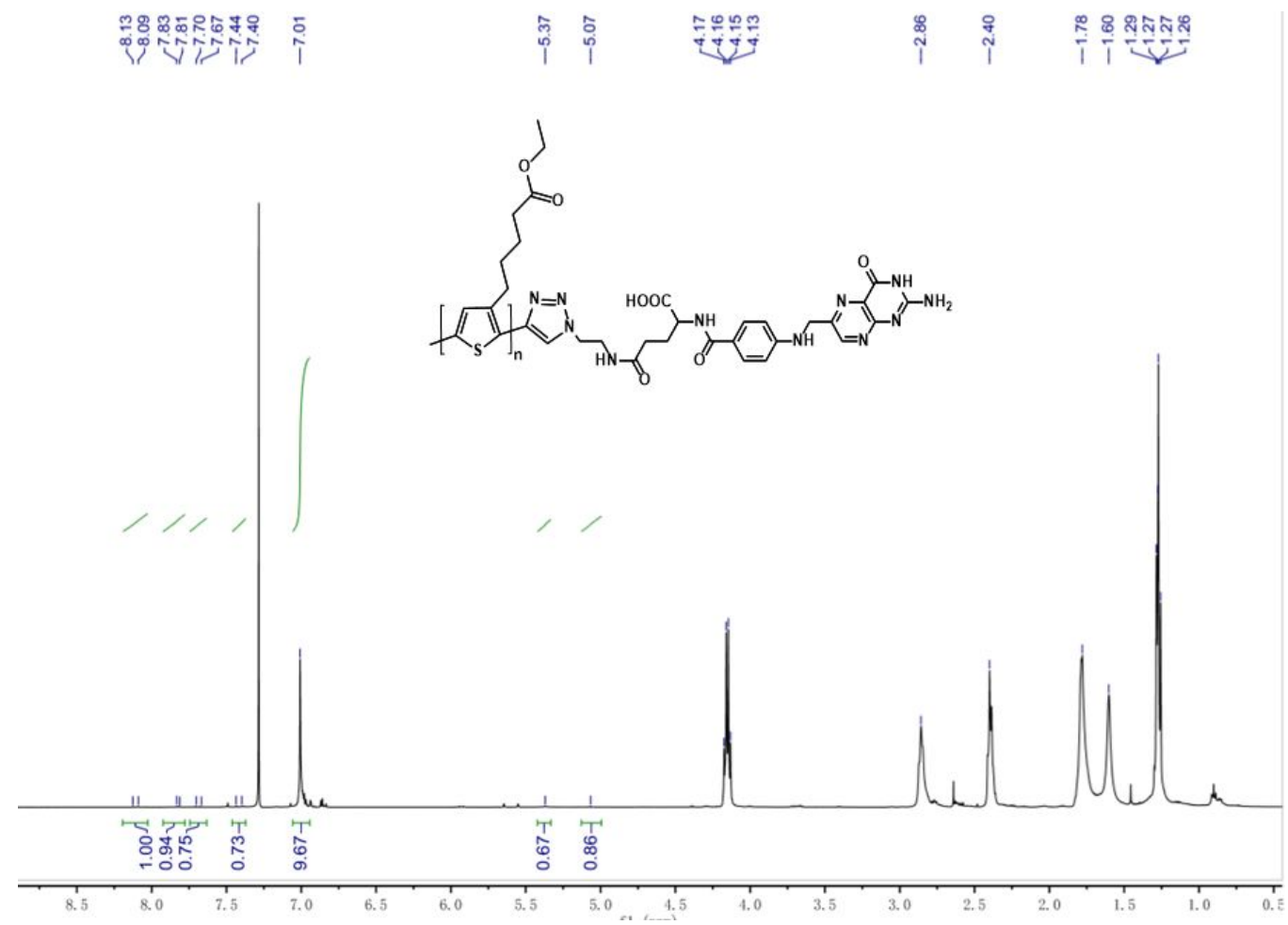

Figure S8. ${ }^{1} \mathrm{H}$ NMR spectrum of P3EPT-FA in $\mathrm{CDCl}_{3}$.

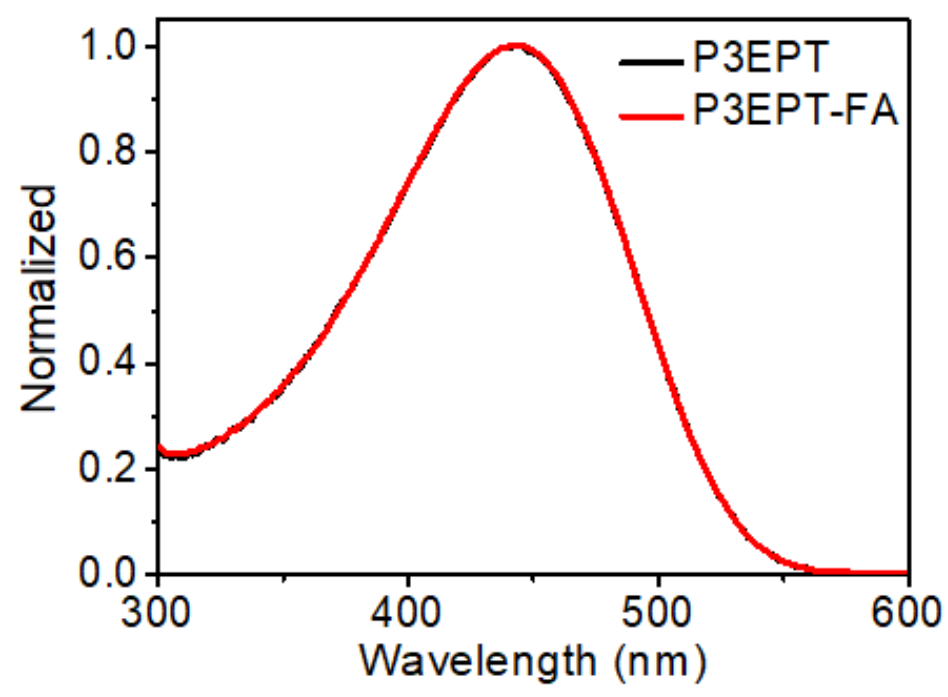

Figure S9. The normalized UV-vis absorption spectra of P3EPT (black line) and P3EPT-FA (red line) in THF solution. 


\begin{tabular}{cccccccccc} 
Planar & & & & $\mathrm{h}$ & $\mathrm{r}$ & $\theta$ & $\mathrm{S}$ & Array & $\mathrm{S}$ \\
- & 14.6 & 7.3 & 1556.068 & 14.6 & 0 & 180 & 0 & & \\
P3EPT & 15 & 7.5 & 22.5 & 12.43 & 5.6519996 & 131.09681 & 100.35849 & 117.08491 \\
P3EPT-FA & 18.1 & 9.05 & 27.15 & 9.35 & 9.0450263 & 91.899656 & 257.02155 & 299.85847 \\
Petri dish & 20 & 10 & 30 & 8.51 & 9.888372 & 81.43102 & 307.18462 & & \\
\hline
\end{tabular}

(a)

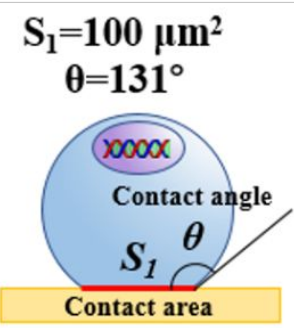

(b)

Micro-fabricating

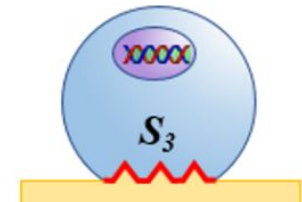

$\mathrm{S}_{3}=117 \mu \mathrm{m}^{2}$ (c)

$$
\begin{gathered}
\mathrm{S}_{2}=257 \mu \mathrm{m}^{2} \\
\boldsymbol{\theta}^{\prime}=92^{\circ}
\end{gathered}
$$

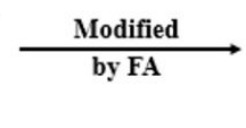

(d)
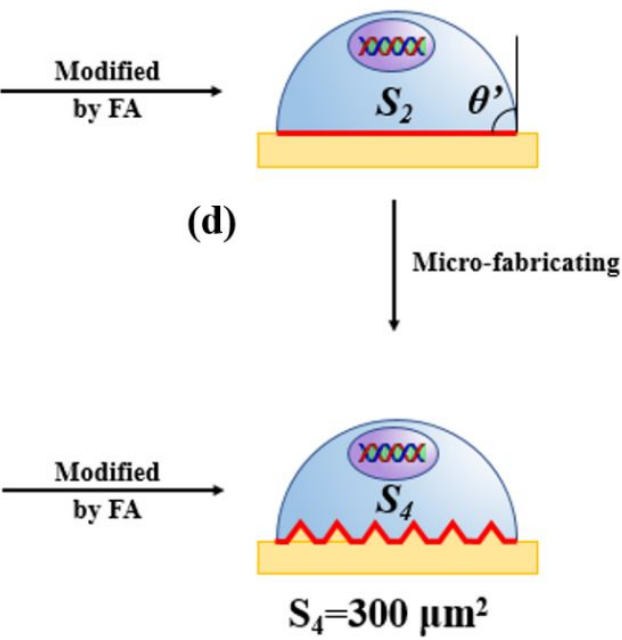

Figure S10. The simulation of contact angles and areas ${ }^{3}$ between N2A cells and

P3EPT (a) planar and (b) array films; P3EPT-FA (c) planar and (d) array films.

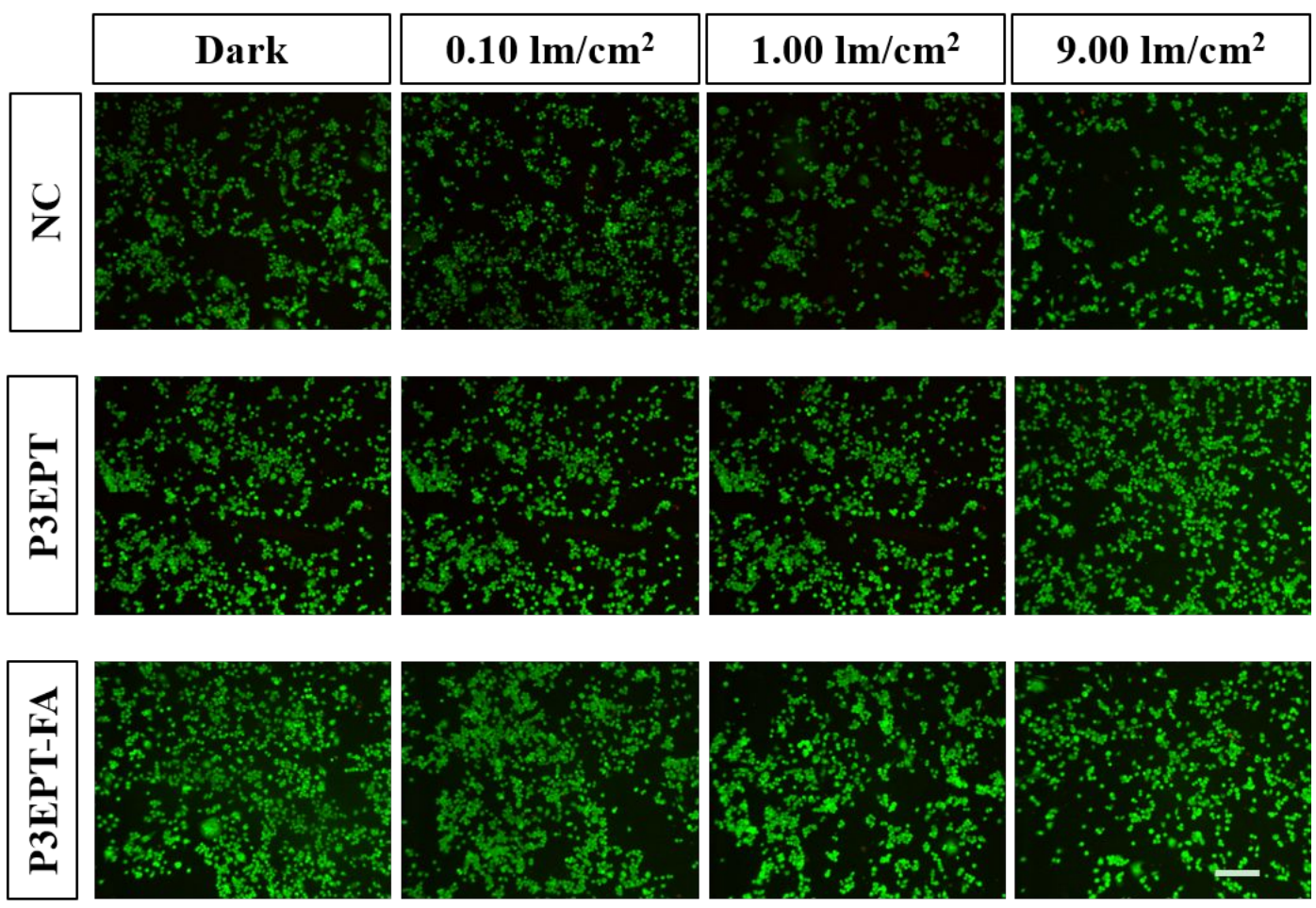


Figure S11. Cellular-viability assessment of N2A cells. The cells were seeded on different substrates under dark or light condition; the scale bar is $50 \mu \mathrm{m}$. The cells were stained with AO/PI.

(a)

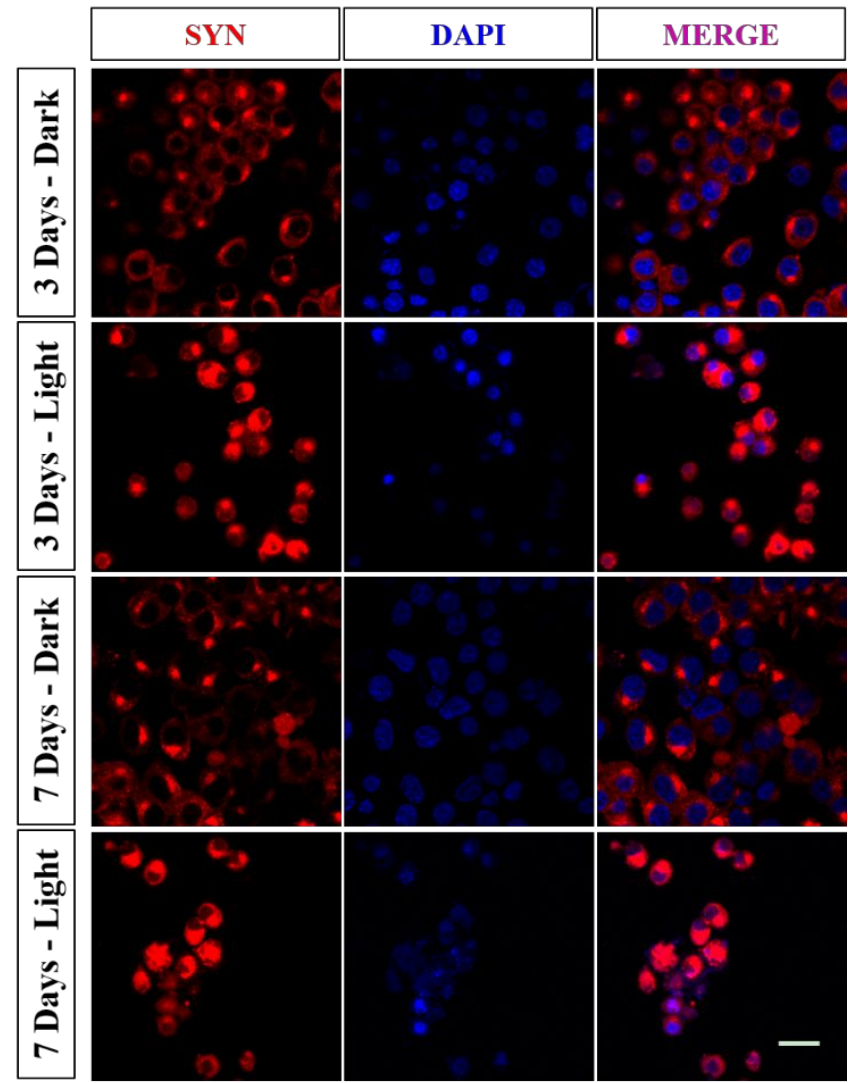

(b)

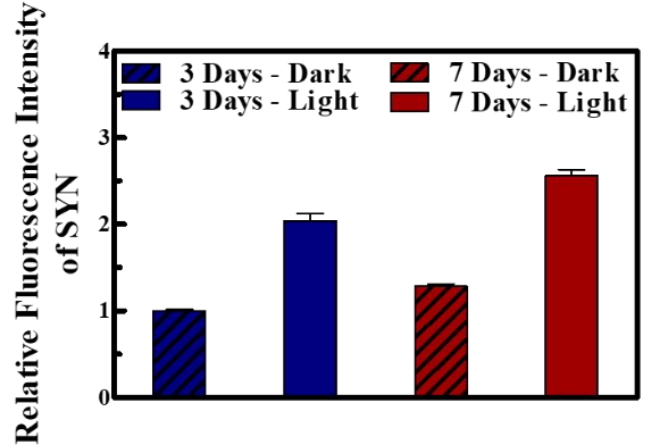

Figure S12. Synaptophysin expression in nerve cells. (a) Immunofluorescence images of SYN in N2A cells; the scale bar is $20 \mu \mathrm{m}$. (b) Relative SYN immunofluorescence intensity of the cells in different groups. 


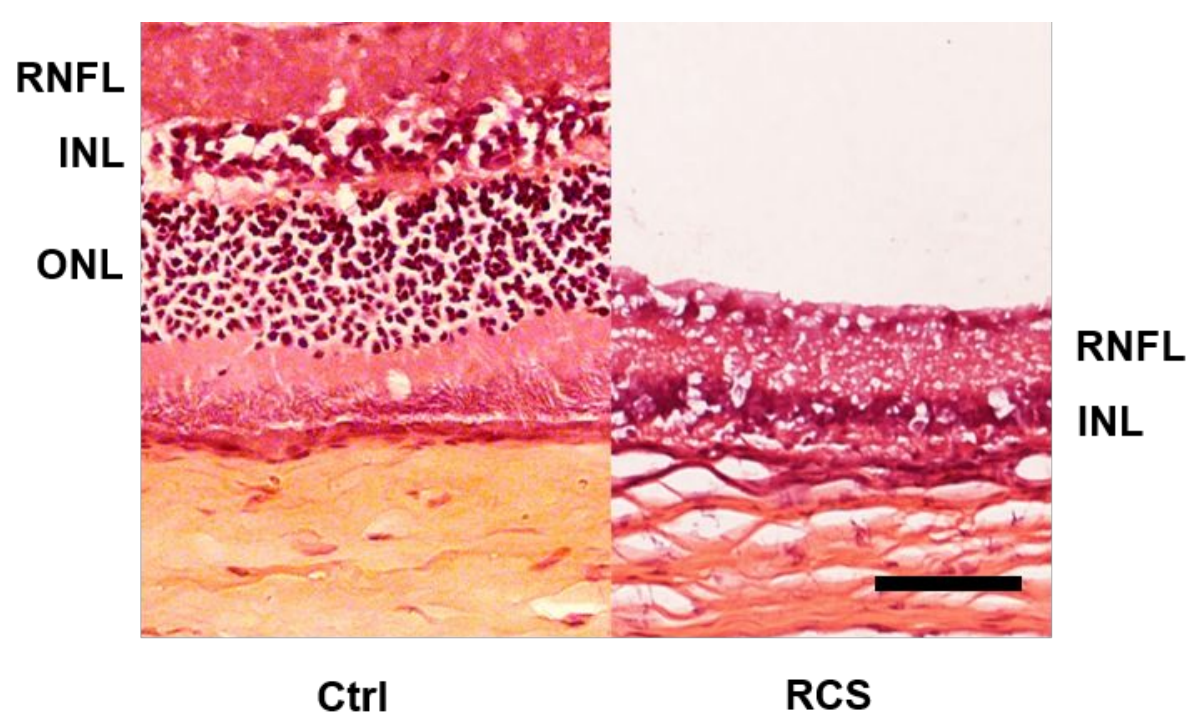

Figure S13. Hematoxylin \& eosin-stained histological sections of Sprague-Dawley (SD) rat retina and RCS rat retina. The scale bar denotes $10 \mu \mathrm{m}$. RNFL: retinal nerve fiber layer; INL: inner nuclear layer; ONL: outer nuclear layer.

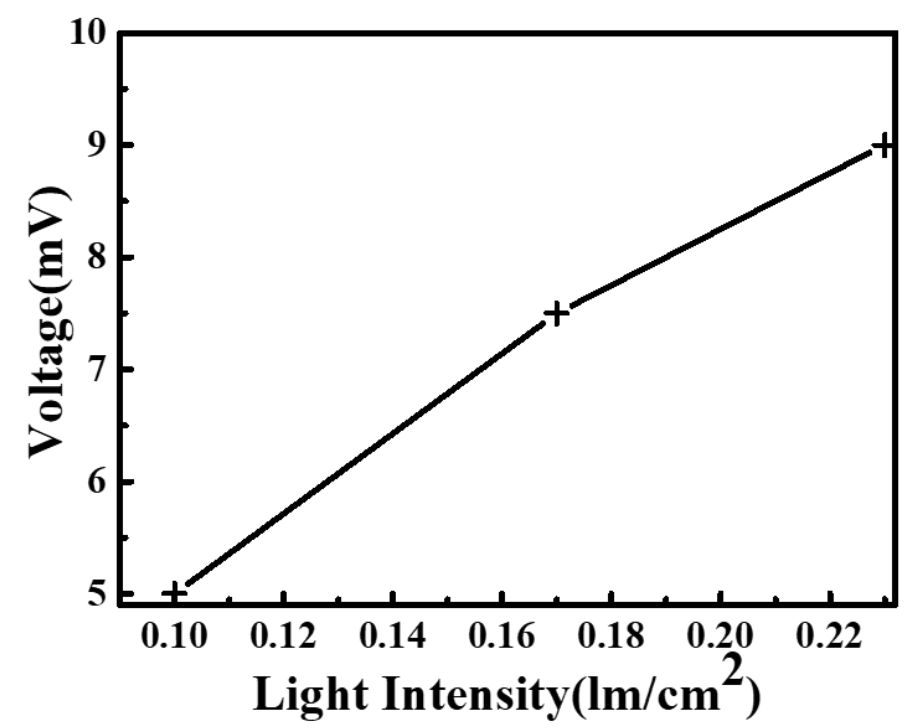

Figure S14. Voltage response curve for the artificial retina illumined by white LED. 

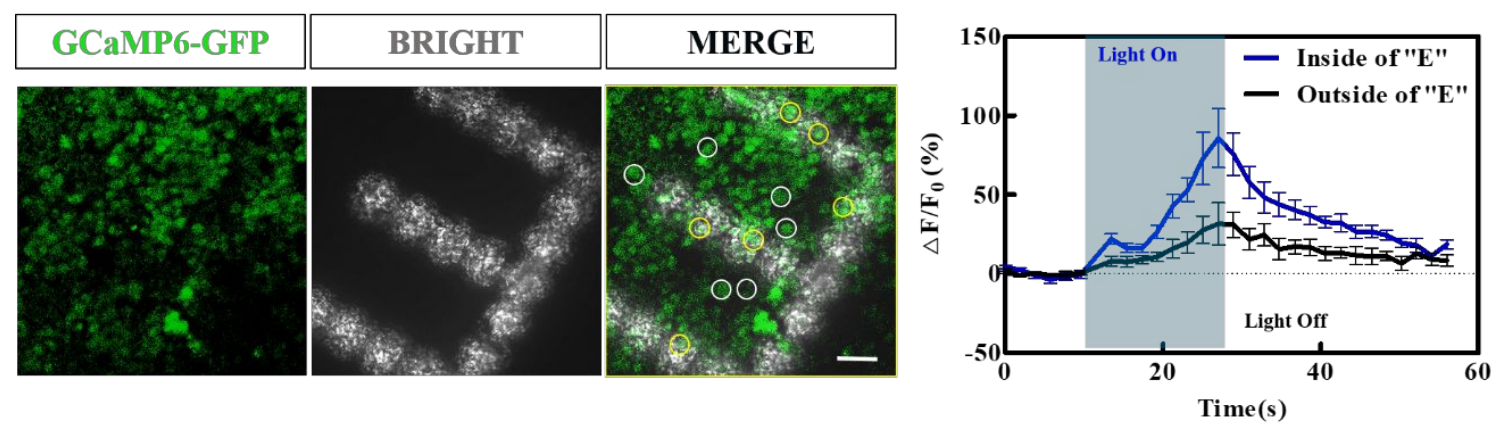

Figure S15. (Left) Fluorescence images of the nerve cells illumination by blue LED with power of $9.00 \mathrm{~lm} / \mathrm{cm}^{2}$. The scale bar is $50 \mu \mathrm{m}$. (Right panel) Fluorescence traces indicating the change of intracellular calcium ion concentration for the cells under light and in dark (six cells were selected for each group).

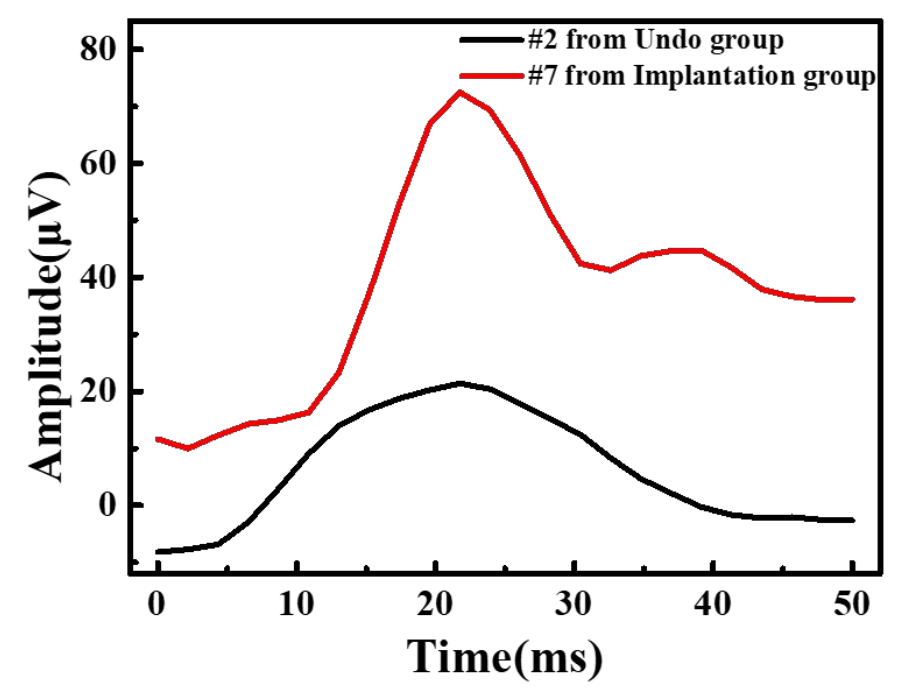

Figure S16. The raw VEP recorded from the animals with and without the prosthesis by an electrophysiological diagnostic system (Roland Consult, Reti-port/ scan21). 
A.

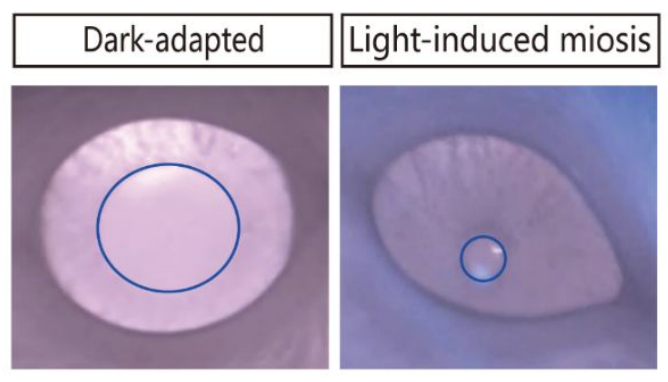

B.

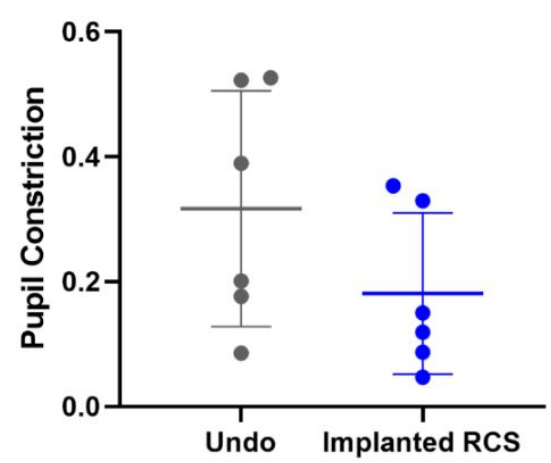

Figure S17. Rescue of the pupillary reflex. A, Constriction of the pupil by light pulses as assessed using standard infrared imaging in the implanted RCS rats. B, The changes of PLR showing a restoring trend in the implanted rats. Pupil constrictions (means \pm SEM) were: undo, $0.32 \pm 0.08(\mathrm{n}=6)$; implanted RCS rats, $0.18 \pm 0.05(\mathrm{n}=6)$. Unpaired Student's t test, $\mathrm{p}=0.17$.

Table S1. The original VEP data.

\begin{tabular}{|c|c|c|c|c|c|c|c|}
\hline & Eye number & VEP1 & VEP2 & VEP3 & VEP4 & VEP5 & Average \\
\hline \multirow[t]{8}{*}{ undo } & $\# 1$ & 27.8 & 63.8 & 59.6 & 29.0 & 57.7 & 47.58 \\
\hline & $\# 2$ & 23.3 & 79.0 & 48.3 & 52.1 & 43.5 & 49.24 \\
\hline & $\# 3$ & 29.5 & 37.7 & 15.8 & 17.5 & 8.8 & 21.86 \\
\hline & $\# 4$ & 47.0 & 42.6 & 77.4 & 46.8 & 47.9 & 52.34 \\
\hline & $\# 5$ & 90.0 & 82.2 & 61.7 & 51.5 & 66.0 & 70.28 \\
\hline & $\# 6$ & 46.1 & 42.9 & 51.4 & 45.8 & 45.6 & 46.36 \\
\hline & $\# 7$ & 64.2 & 53.8 & 45.3 & 48.6 & 47.8 & 51.94 \\
\hline & $\# 8$ & 62.3 & 57.1 & 28.2 & 95.5 & 42.2 & 57.06 \\
\hline
\end{tabular}




\begin{tabular}{|c|c|c|c|c|c|c|c|}
\hline & $\# 9$ & 81.9 & 64.0 & 30.9 & 52.3 & 61.3 & 58.08 \\
\hline & $\# 10$ & 37.7 & 35.8 & 31.7 & 38.0 & 58.3 & 40.30 \\
\hline & \#11 & 49.8 & 60.8 & 65.1 & 41.7 & 39.6 & 51.40 \\
\hline \multirow[t]{9}{*}{ RCS } & $\# 1$ & 70.8 & 40.7 & 67.8 & 89.3 & 40.2 & 61.76 \\
\hline & $\# 2$ & 46.6 & 45.8 & 45.4 & 49.2 & 383.1 & 114.02 \\
\hline & $\# 3$ & 81.3 & 69.5 & 24.2 & 33.2 & 44.3 & 50.50 \\
\hline & $\# 4$ & 41.1 & 89.5 & 83.6 & 66.9 & 42.1 & 64.64 \\
\hline & $\# 5$ & 83.0 & 44.1 & 82.6 & 58.4 & 76.9 & 69.00 \\
\hline & $\# 6$ & 146.4 & 97.9 & 51.7 & 64.9 & 80.0 & 88.18 \\
\hline & $\# 7$ & 80.7 & 68.3 & 77.4 & 71.9 & 76.8 & 75.02 \\
\hline & $\# 8$ & 47.8 & 85.8 & 95.0 & 51.9 & 76.9 & 71.48 \\
\hline & $\# 9$ & 107.7 & 153.9 & 42.7 & 62.2 & 69.3 & 87.16 \\
\hline
\end{tabular}

* We recorded 5 times for each eye and the average values were used for the final analysis. 
A.

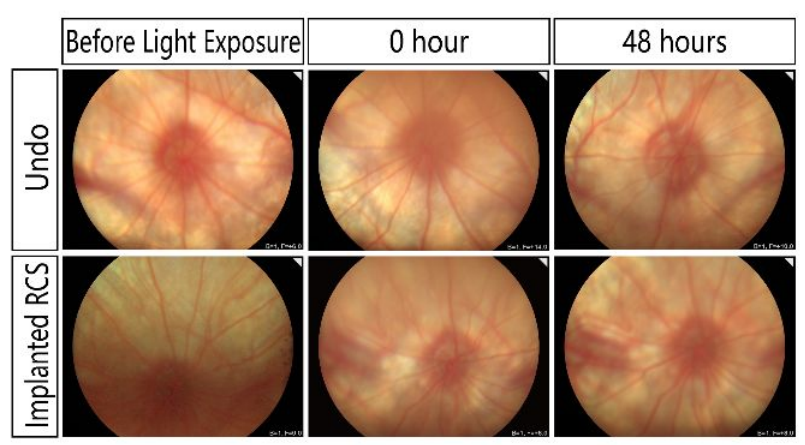

B.

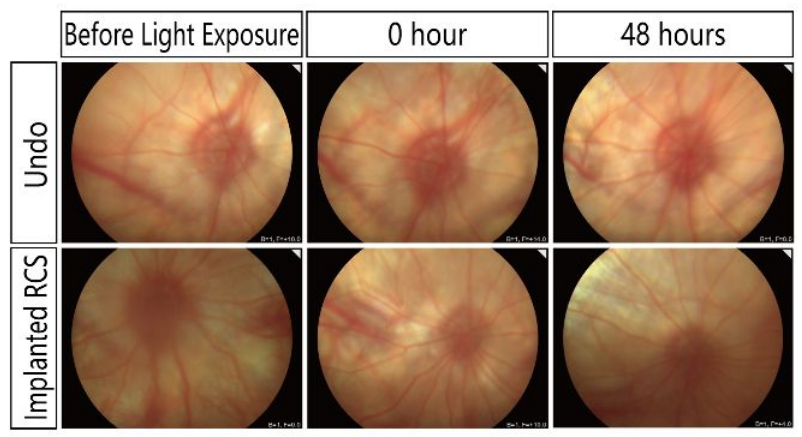

Figure S18. Fundus condition after red and blue light irradiation. A. The condition of the fundus after red light irradiation (1400 lux; $5 \mathrm{~min})$. B. The condition of the fundus after blue light irradiation. The light source was replaced by blue light (1400 lux; 5 min), other conditions are the same as in A.

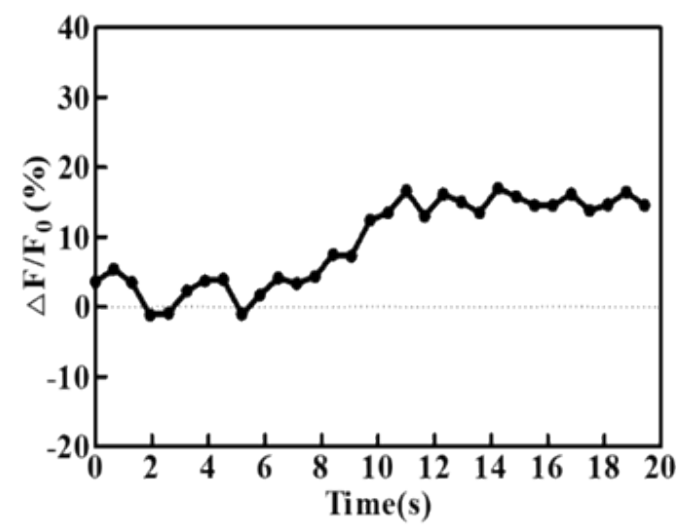


Figure S19. Fluorescence traces indicating the change of intracellular calcium ion concentration for the single cell.

We used albino RCS rats (Figure S20). In the RCS rat model used, degeneration starts at approximately 12 days, and the photoreceptors are completely degenerated by approximately 77 days $^{4}$. So we operated rats at 2-3 months of age. Based on previous explorations and researches on the occurrence and development of retinal degeneration in RCS rats, many RP therapeutic operations were performed around the 21 st day after birth $^{5-6}$. We took into account the above reasons, so we operated at 2-3 months of age.

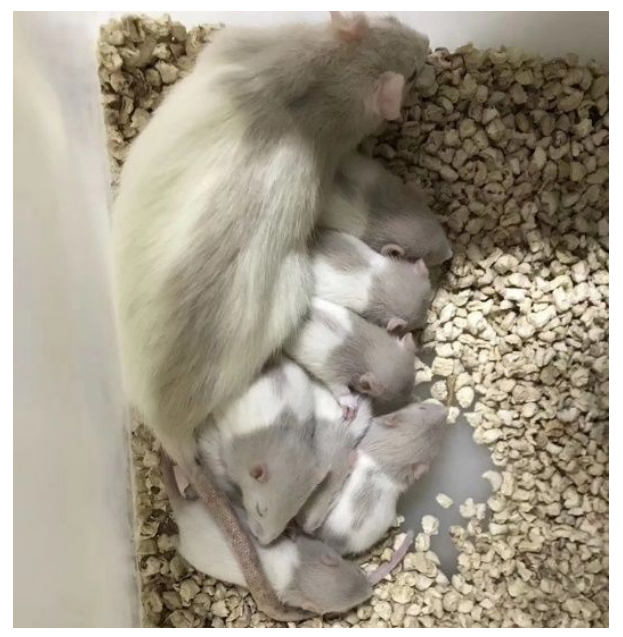

Figure S20. A photograph of albino RCS rats.

\section{REFERENCES}

1. Motiwala, H. F.; Vekariya, R. H.; Aube, J., Intramolecular Friedel-Crafts Acylation Reaction Promoted by 1,1,1,3,3,3-Hexafluoro-2-propanol. Org Lett 2015, 17 (21), $5484-5487$. 
2. Mishra, K.; Joy, A., Dual Functionalized Telechelic Block Copolymers with Reproducible Block Sizes Prepared by Microwave Assisted RAFT Polymerization. Polymer 2015, 66, 110-121.

3. Erbil, H. Y., The Debate on the Dependence of Apparent Contact Angles on Drop Contact Area or Three-Phase Contact Line: A Review. Surface Science Reports 2014, $69(4), 325-365$.

4. LaVail, M. M.; Battelle, B. A., Influence of Eye Pigmentation and Light Deprivation on Inherited Retinal Dystrophy in the Rat. Exp Eye Res 1975, 21 (2), 167192.

5. Ciavatta, V. T.; Mocko, J. A.; Kim, M. K.; Pardue, M. T., Subretinal Electrical Stimulation Preserves Inner Retinal Function in RCS Rat Retina. Mol Vis 2013, 19, 995-1005.

6. Pardue, M. T.; Phillips, M. J.; Yin, H.; Sippy, B. D.; Webb-Wood, S.; Chow, A. Y.; Ball, S. L., Neuroprotective Effect of Subretinal Implants in the RCS Rat. Invest Ophthalmol Vis Sci 2005, 46 (2), 674-682. 